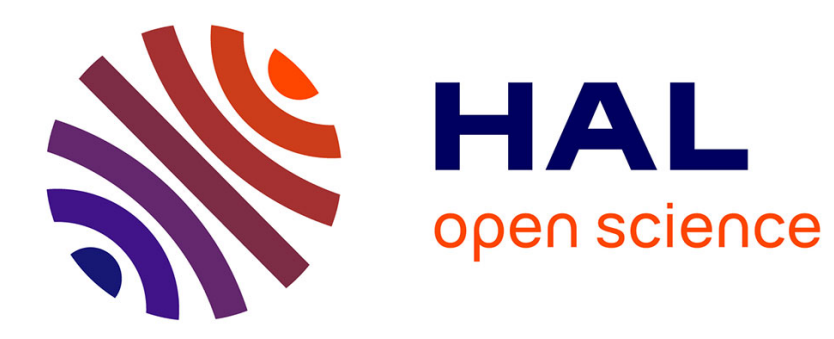

\title{
Development Trends Of The Private Law Of France
}

\author{
A. Kostruba, M. Khomenko
}

\section{To cite this version:}

A. Kostruba, M. Khomenko. Development Trends Of The Private Law Of France. Journal of the National Academy of Legal Sciences of Ukraine, 2018, 25 (2), pp.156-173. 10.31359/1993-0909-201825-2-156 . hal-02334642

\section{HAL Id: hal-02334642 \\ https://hal.science/hal-02334642}

Submitted on 27 Oct 2019

HAL is a multi-disciplinary open access archive for the deposit and dissemination of scientific research documents, whether they are published or not. The documents may come from teaching and research institutions in France or abroad, or from public or private research centers.
L'archive ouverte pluridisciplinaire HAL, est destinée au dépôt et à la diffusion de documents scientifiques de niveau recherche, publiés ou non, émanant des établissements d'enseignement et de recherche français ou étrangers, des laboratoires publics ou privés. 
Михайло Михайлович Хоменко

Кафедра иивільного права Київський наиіональний університет імені Тараса Шевченка Київ, Україна

\title{
ТЕНДЕНЦІї РОЗВИТКУ ПРИВАТНОГО ПРАВА ФРАНЦЇ̈
}

\begin{abstract}
Анотація. Стаття присвячена дослідженню сутності та змісту трансформацій у сфері приватного права Франиузької Республіки в контексті євроінтеграційних процесів сьогодення, а також розробиі наукових висновків. За результатами проведеного дослідження було наведено загальну характеристику правової системи Франиузької Республіки, виокремлено ї̈ особливості; розкрито й узагальнено історико-правові засади генези реформування приватного права Франиузької Республіки в контексті євроінтеграцї; виявлено особливості реформаційного впливу євроінтеграчійних процесів на досліджувані трансформації у сфері приватного права; запропоновано чотири періоди реформування приватного права Франиузької Республіки, зокрема: периий - «кольберівський»; другий - «наполеонівський»; третій - «інтеграційний»; четвертий - «сучасний»; обтрунтовано необхідність та нагальність розробки й прийняття Кониепиії реформування приватного права Франиузької Республіки. Проведена робота надала змогу сформулювати теоретичні висновки та окреслити перспективи подальшого розвитку приватного права Франиузької Республіки в контексті євроінтеграції з урахуванням необхідності збереження державної ідентичності та світової значущості.
\end{abstract}

Ключові слова: Кодекс Наполеона, правова система, Свропейський Союз, реформаційний вплив, кодифікація.

\section{Анатолий Владимирович Коструба}

Кафедра гражданского права Прикарпатский национальный университет имени Василя Стефаника ИваноМихаил Михайлович Хоменко

Кафедра гражданского права Киевский наииональный университет имени Тараса Шевченко, Киев, Украина

\section{ТЕНДЕНЦИИ РАЗВИТИЯ ЧАСТНОГО ПРАВА ФРАНЫИИ}

Аннотация. Статья посвящена исследованию сущности и содержания трансформаций в сфере частного права Франиузской Республики в контексте евроинтеграционных прочессов настоящего времени, а также разработке научных выводов. По результатам 
проведенного исследования приведена общая характеристика правовой системь Франиузской Республики, выделены ее особенности; раскрыты и обобщены историко-правовые основы генезиса реформирования частного права Франиузской Республики в контексте евроинтеграции; выявлены особенности реформационного влияния евроинтеграционных процессов на исследуемые трансформации в сфере частного права; предложено четыре периода реформирования частного права Франиузской Республики, в частности: первый - «кольберовский»; второй - «наполеоновский»; третий - «интеграционный»; четвертый - «современный»; обоснована необходимость и актуальность разработки и принятия Концепции реформирования частного права Франиузской Республики. Данная работа способствует формированию теоретических вьводов и перспективам дальнейшего развития частного права Франщузской Республики в контексте евроинтеграции с учетом необходимости сохранения государственной идентичности и мировой значимости.

Ключевые слова: Кодекс Наполеона, правовая система, Европейский Союз, реформационный влияние, кодификация.

\author{
Anatoly V. Kostruba \\ Department of Civil Law \\ Vasyl Stefanyk $P_{\text {recarpathian National University }}$ \\ Ivano-Frankivsk, Ukraine \\ Mykhailo M. Khomenko \\ Department of Civil Law
}

Taras Shevchenko National University of Kyiv,

Kyiv, Ukraine

\title{
DEVELOPMENT TRENDS OF THE PRIVATE LAW OF FRANCE
}

\begin{abstract}
The article is devoted to the establishment of the essence and content of the transformations in the field of private law of the French Republic in the context of today's European integration processes as well as the development of scientific conclusions. According to the results of the study, a general description of the legal system of the French Republic was presented, its features were singled out; the historical and legal foundations of the genesis of reforming the private law of the French Republic in the context of European integration are revealed and summarized; the peculiarities of the reformist influence of European integration processes on the investigated transformations in the field of private law are revealed; four periods of private law reform in the French Republic were proposed, in particular: the first-Colbert's; the second - "Napoleon's"; the third - "Integration"; the fourth - "Contemporary"; The necessity of the development and adoption of the Concept of private law reform in the French Republic was substantiated. The work provided the opportunity to formulate theoretical conclusions and outline the prospects for the further development of the private law of the French Republic in the context of European integration, taking into account the need to preserve national identity and world significance.
\end{abstract}

Keywords: Napoleonic Code, legal system, European Union, reformation influence, codification. 


\section{INTRODUCTION}

The recent years have been characterized by the multilateral development of international cooperation and interaction at different levels: between states, commercial structures, public organizations, academic communities. The multifaceted cooperation covers not only the sphere of state, business and private relations, thus creating the need for their updated legal regulation. The above summary sets the objective preconditions for raising the focus on private law. The European Union is a unique entity that can be considered as the foundation for solving globalization challenges of our time, as within the framework of the united Europe there is an opportunity for the participating states to solve key problems of socio-economic, political, cultural, ecological development and issues of internal and external security. In the EU law various legal cultures, traditions and norms, transformed fragmentarily by the national peculiarities of each participating state-member, have been united, leading in its consequence to the formation of a powerful and effective regulator of social relations in the union. Consequently, the convergence of the legal systems of the Community members is an indispensable qualitative feature of its development and integrates the innovations in the national legal systems.

The Community enlargement process has raised before the whole association in principle and, France in particular a number of serious challenges that led to a rapid adjustment of the development vectors of private law in the country. The French legal system itself relates to the matrix law and order of the modern legal world. The development models, selected by French lawyers to generate national law, have become the conceptual and normative basis for the development of legal systems all over the world. Famous French comparativist R. Leger even relates it to the so-called "Great legal systems of the present". It should be noted that just the only civilization heritage of this country, which has been formed for centuries, led to enormous legal transformations around the world, providing impetus to the rapid development of jurisprudence as such [1].

Thus, the French Republic has a long legal history, and at present the regulatory and legal acts of the Napoleonic era remain its foundation. It is generally acknowledged that, despite the introduction of numerous changes and additions, the foregoing sources of law are considered as outdated, so in today's world, France is characterized by a significant legal monolith of archaic codification. The issue of the attractiveness of French law and its influence have become a significant impact in France after the bicentennial of the Civil Code [2]. The nature and format of civil and commercial (business) relations objectively has a certain specificity of their legal regulation, which determine the use of separate legal means in this process. The abovementioned not so much separates the commercial (entrepreneurial) right from the civilian one, as it specifies it within the civilist system. Today, the French Republic comprehensively and conceptually approaches the development and improvement of national legislation, which is why many countries are recognized as an example of up-dating the implementation of reform measures and unification of their results [3]. 
In particular, over the past 20 years, significant changes have been made to national legislation directly related to the influence of the European Union, since, in accordance with article 55 of the Constitution of 1958, international law prevails over domestic law [4]. Legislative transformations take place through coverage of recent European and international trends, without complex blind copying or subordination to European norms. Thus, in the context of the limited resources and capabilities of France, the European integration impetus is considered as an instrument for implementing its foreign policy strategy. The composition of Europe as an international authority (Europepuissance) should increase the influence and significance of France in the world, which, in its turn, implies the need to ensure the leading role of the country in the EU, its activity and initiative [5].

At the same time, in view of the above-mentioned conditions, for the present stage of the development, the private law science is characterized by a rising interest to the study of its practical and mostly rather specific issues. At the same time, due attention is not always paid to the consideration of the leading theoretical aspects of the private law of the French Republic in the context of European integration. Issues of future transformations of both the entire legal system and the sphere of private law of France under the conditions of a globalized world, the preservation of the state identity and world significance are of vital importance. Reformational legal relations in the field of private law of the French Republic are marked by their variability, innovative component and in many respects improve the previous rules developed and applied in cases over the past two centuries. It is advisable to carry out an analysis of the main innovations in order to develop a system of factors that contributed to reformational changes, in conjunction with a comparative analysis of old norms with novelties.

Taking into account the foregoing, the purpose of the article is to determine the essence and content of the transformations in the field of private law of the French Republic in the context of today's European integration processes. In accordance with the stated goal, the following main tasks of the article have been outlined: 1) to present a general description of the legal system of the French Republic, to distinguish its features; 2) to reveal and generalize the historical and legal principles of the private law reformation of the French Republic in the context of European integration; 3) to identify the peculiarities of the reformational influence of the European integration processes on the investigated transformations in the field of private law; 4) to formulate theoretical conclusions and outline the prospects for the further development of the private law of France, based on the results of the analysis. The private law of France, as a branch of legal science, has a long history of appearance and development; its theoretical foundations were disclosed in the works of P. Asner, K. Bickerton, F. Bozo, P. Bonifas, T. Homar, J. Hubert-Rodier, J.-P. Darny, A. Dumoulin, E. O. Obichkina, V. Pertuso, J. Rubinsky, S. Serfati, P. Timofeyev, J. Fardo and others.

Considerable attention is paid to the reform of compulsory law in professional French literature. In particular, it is a question of the study of F. Ansel, M. Latin [6], 
B. Fowarck-Cosson and J. Gest [7], F. Terre [8], F. Stoffel-Munk [9], G. Shantepi [10] and others. Political scientists also indirectly involved in their work the questions of private law. Thus, the study of the European dimension of the foreign policy of the French Republic predetermines scientific interest to the problems of transformations and the sphere of private law, in particular, the works of scientists are devoted to the analysis of various aspects of the state's activities in international relations in the postbipolar age and are based on the theories of multidimensionality and dynamism of political processes, analysis of the main characteristics of reforms at the national and European levels, in view of the regional integration program declared by France.

\section{MATERIALS AND METHODS}

The methodological basis of the article is the following methods: dialectical, system and structural analysis, functional, sociological, formal-dogmatic, historic and legal, synergetic, method of legal modeling, comparative-historical, and others.

A special place has been given to dialectical and synergetic methods of cognition. The first is manifested in the fact that its provisions and requirements make it possible to trace the development of the French system of private law, to consider it not as static, but as constantly evolving phenomenon. In addition, this method allows determining the state, trends and prospects for the development of scientific research in the given field. The use of the synergetic method allows to simulate a map of the transformational possibilities of the field of private law and its elements. In the light of the ideas of synergetics, the internal logic of the development of the investigated branch and its core are traced. In this case, its reformation will become not a process of imposing an external and artificial for it legal method, but, on the contrary, it will manifest itself as a logical legal process.

Through the historical and legal method, the formation and development of legal foundations for the reformation of the private law of the French Republic have been studied. The comparative historical method by comparative opposition of archaic articles and novelties allowed to distinguish the most significant changes in the system of private law in the context of European integration. In addition, this method has allowed substantiating the proposed authoritarian periodization of the reform of private law in France. The formal-dogmatic method was used to identify relationships and contradictions in the developmental periods that were proposed by scientists in the field of the theory of private law. It should also be noted the legal modeling method as well, which gave an opportunity to predict the potential prospects for the further development of private law of France in the light of European integration processes and to propose to the development and adoption of the Concept for reforming private law of the French Republic.

\section{RESULTS}

The final rooting of the continental-European style of legal thinking on the French social basis occurred at the end of the eighteenth century, substantiating the doctrine of the unity of the French legal system. This fateful turn in its history, the country is defi- 
nitely obliged to political events of 1789 . Since then, only the law has had the right to restrict the freedom of the individual, it also guaranteed the equality of citizens in the realization of their personal and property rights.

In its structural composition, the genetic roots of the French legal system extend back to the Roman tradition of the division of the law to private and public, vertical architectonics has an explicit cross-sectional nature of construction, and directly the sectoral approach to law has certain specific features [11].

The legal system of the French Republic is distinguished by the duality of private law, which lies in the separation of legal norms in the regulation of commercial (trade) activities from the norms of civil law. Such a phenomenon should be considered as a form of internal distribution that does not violate sector integrity and allows taking into account the peculiarities of legal regulation of commercial relations. Consequently, the relevant commercial relations do not contradict the civil ones and emphasize a certain level of their systemic differentiation within a single civilized approach. The country under investigation is globally known for its distinct, codified regulatory and legal framework in the above area. Thus, R. Kabriak notes that in France the doctrine of codification is historically one of the sections of civil law science, and it were mainly civilians who formed it [12]. O. V. Kazakova, in turn, emphasizes that the methodology of codification of the French type cannot be blindly copied by other states, given that it is adapted specifically for its own legal system [13]. Taking into consideration the international significance of the regulatory and legal framework for the existence of the field of private law of the French Republic, it is expedient to propose own periodization of its reformation.

The analysis of national regulatory and legal acts of France shows that the periodization of private law of France can be started with the emergence of trade law, in particular, in 1563 in the era of Charles XX when "Ordinance on trade" was adopted (which was issued at the request of the merchants, for the purpose of introducing to the trade the principle of decency to reduce disputes between traders). In 1673, the Commercial Code (Ordinance on Land Trade) was adopted; in 1681 - the Marine Code ("Ordinance on Maritime Trade"), which became known as "Colbert's Ordinance". Taking into account the above, it can be stated that the trade legislation was the first and foremost to be codified. The first period should be defined as "Colbert's period".

The beginning of the second period, the "Napoleonic period", is definitely related to the codification held at the time of the reign of Napoleon Bonaparte. "Code civil des francaise" was adopted on March 21, 1804, and constituted a set of unified laws that operate throughout the country and have a special structure and logic of representation (by institutions), which contain precise legal definitions or conditional legal terminology (civil death, etc.). It can be stated that the civil law of France was codified only 130 years after the commercial law [14].

The code replaced about 360 local sets of coutumes (legal norms) and became accessible to all citizens by the unity of clear and understandable laws. In particular, the 
Civil Code consolidated the gains of the French Revolution, laid the foundation for the codification of law in Europe and became the foundation of the Roman civil law tradition. During his development, special attention was paid to the clarity and consistency of the wording. This regulatory and legal act contains the fundamental provisions on the right of private property, compensation for damages, contractual law, and others. Its structure involves an introductory title, the first book "On Individuals", the second book "On Property", the third book "On Different Methods to Acquire the Ownership" altogether 36 titles and 2281 articles. It should be noted that a significant number of articles of the Code has never changed for 200 years. This codified regulatory and legal act has played a huge role in strengthening bourgeois relations in France and become in fact, the ideological "core" of the revolution, and subsequently was recognized as the patron of the Belgian, Bulgarian, Spanish, Italian, Polish and Swiss Civil Codes. Civil law has played its role in the fundamental field of law, and as a result of expanding the subject of its regulation, in most social relations in the field of private law.

The same period includes the Commercial Code of France, adopted on September 15,1807 , which contained 648 articles and united all the current at that time, regulations governing the relations of trade. Within the framework of the law reform of France a separate legislative act "On Companies", was adopted on July 24, 1867.

It can be considered as a characteristic that the issues of entrepreneurial activity, which needed to be dealt with, received their legislative regulation, not by improving the existing codified act, but through the adoption of autonomous legislative acts on specific issues. Thus, the legal regime of business was determined by the laws of 1909 (the Law "On the sale and pledge of goodwill" of March 17, 1909) and of 1935 (the Law "On the sale price of business" of June 29, 1935) without codification. The same applies, for example, to the commercial lease, which was the subject of specific rules since 1953 (Decree of September 30, 1953, No. 53-960, which regulates the relationship between lessors and lessees in the renovation of the lease of a building or premises for commercial, industrial or artisan use) [15].

It would be appropriate to link the launch of the third integration period of reforming of private law in France to a major event for the whole of Europe, when, along with Belgium, Italy, Luxembourg and the Netherlands, France became the pioneer of the European integration movement by signing the Treaty of Establishing the European Coal and Steel Association in Paris on April 18, 1951, and later the Treaty on the European Union. It is these regulatory acts that have led to a gradual, powerful reform movement in the field of private law and have become the so-called "road map" of reforms.

The constitutional basis for the expanding of European law in the French legal space was set much later by Article 88-1 of the Constitution, enacted by the Constitutional Law No. 92-554 of June 25, 1992, which provides that "the Republic shall participate in the European Communities and in the European Union, formed by the states which entered them freely for the joint exercise of the defined competence on the basis of the international treaties that these states had developed. The Republic may participate in 
the European Union subject to the conditions laid down in the Lisbon Treaty signed on December 13, 2007, replacing the Treaty on European Union and the Treaty establishing the European Community" [16].

In a context of increasing globalization, the French legal system is undergoing increasing transformations. These include, in particular, the increase of the level of its convergence and internationality, the transformation within the regulatory (regimes of supplementing and replacing regulatory and legal norms), interpretative (expanding the basis of reasoning when making judgments) and the law-enforcement components of the legal system.

Thus, with the creation of the European Union, the investigated legal system has acted as a matrix beginning for various borrowing options in the law. The greatest influence of French law was designed on the territory of the colonial rule of France. The dispersion of French law has manifested itself in the specified regions in two main directions: 1) regulatory (the influence of the French right on formation of colonial territories); 2) value (the complexity of the overall range of social and ethical grounds in the legal existence of the African and Malagasy regions).

However, subsequently the private law of the French Republic, designated by the unique archaism, was forced to undergo reformational changes. The root cause of the reforms became the realization that the impact of the Civil Code abroad had diminished. Initially, this document served as a source of inspiration and, as already noted, even a pattern in many countries of Europe, Africa, Asia, Central and South America and some parts of North America [17]. France has become one of the few legal systems that have had such a dominant influence on other legal systems, therefore, the country is generally considered to be the "dominant jurisdiction" of the whole legal family which expanded from Chile to Vietnam. Its phenomenal international flow has brought pride among French lawyers, for whom the Code has become "a symbol of national identity" [18]. Reducing the influence of the Code of Napoleon has become essential at the turn of the 21 st century. In particular, countries such as the Netherlands, Canada (Quebec) and Germany, which had once used it, departed from probing it after reforming their own civilian legal regulations.

Another factor that has led to transformations in private law field was the harmonization of European Union treaties that went beyond consumer protection. The European Parliament has called to work on the European civil or contractual code [19] and, according to the report of 2001 the European Commission has begun debates on the future of European contractual law [20]. These projects caused concern and even hostility in France, partly because they were developed with a relatively small contribution from French lawyers, and threatened to create an influential rival to the Civil Code. However, as of today, no European civil or contractual code has been adopted.

The above factors made the French legislators aware of the fact that the Civil Code would not have a sufficiently powerful further influence on the European level, taking into consideration such a significant gap between its articles and the actual 
state of law. Therefore, prolongation of its existence as a legal model, ready for borrowing by other countries, requires a quality and effective modernization of this regulatory and legal act.

Thus, the Napoleonic design of codification, which perceives it as a process, is associated with the processing of different various sources of law and the creation of a single major act in its place, has been replaced by the principle of so-called "administrative codification", which is not associated with the introduction of amendments directly to the regulatory acts, and does not require interference of the parliament. One more important feature of the represented codification concept is that the code itself consists of two parts - legislative and regulatory. It's exactly the reason why the new codes of the French Republic (Code of Civil Procedure of 1976, Criminal Code of 1994, Commercial Code of 2000 , etc.) tested the abovementioned structural construction.

The Law of July 24, 1966 No. 66-537 "On Commercial Companies" has abolished Title III of the Commercial Code "On Societies" without its updating in the text of a regulatory and legal act. The same applies to Book III, "On insolvency and bankruptcy", which, as a result of the 1967 reform, was abolished and, without replacing its provisions, and included in the Law "On Bankruptcy in Autonomous Legislation" (dated July 13, 1967).

It is appropriate to begin the last, fourth period of the present time with the characterization of the most significant changes and additions which, in particular, concerned inheritance (2001-2006), divorce (2004), the origin of children $(2005,2009)$, securities (2006) , burns (2007), limitation periods (2008), marriage (2013), and others. At the intersection of the periods, in 1999, the Law "On the Civil Solidarity Treaty" was adopted, and in 2013 the law consolidated the right to marry for all types of couples. It should be noted that family law and the right to persons were the areas of limited interference by the legislator, without a doubt, taking into consideration the imperative nature of the legislative norms.

At the intersection of periods in 1999 the new law "On the Civil Contract of Solidarity" and in 2013 the law secured the right to enter into marriage for all kinds of couples were adopted. It should be noted that family law and the right of individuals were areas of limited interference by the legislator, without a doubt, taking into consideration the imperative nature of the legislative norms.

The beginning of this period was also marked by the adoption of the new Commercial Code of the French Republic. The created legal tradition of a separate legal regulation of relations of a commercial nature, which was due to the nature of the social and economic formation of that time, has retained its features at the present stage of the development of the private law of France as well. Since the era of the Napoleonic codifications, commercial law has been recognized without distinction as an independent and original branch of law. Today, the Commercial Code of 2000 (Code de commerce) [21] is in effect in the state. Structurally, it consists of: a legislative part approved by the Ordinance of the Government of France on September 18, 2000, no. 2000-918 [22]; 
the regulatory part, which specifies, develops and amends the legislative part as a form of ensuring its proper application (introduced by the Decree of the Government no. 2007-431 dated March 25, 2007, [23]), a part summarizing the legal provisions suspended. Taken together, the legal act includes nine books and unites 1976 articles distributed by title and chapters in accordance with the subject of legal regulation of a particular type of public relations, regulated by the Commercial Code of France. It can be stated that the current Commercial Code of France has a bicorporal and more divisional structure of regulative material than the Civil Code.

This regulatory and legal act contains provisions defining the types of anticompetitive actions, the nature of the operations leading to concentration, the actions that restrict competition, other prohibited acts, and measures to ensure transparency of activities. Thus, in accordance with Article L 420-1 of the Commercial Code of France, anticompetitive actions are concerted actions of the direct or indirect participation of companies that are part of the group and which are intended to restrict production, goods markets, technical and technological development, investment or control over them; the distribution of markets or sources of supply according to the territorial principle, the range of goods, the volume of their sale or purchase, by the range of sellers, buyers or consumers or by other features, etc. [21]. Particular attention should be paid to the structural content of this regulatory and legal act. Thus, the first book of the Commercial Code of France "On Commerce as a whole" covers 146 articles, which are united in 6 chapters and presented in 4 titles. It reveals the main provisions of commercial activity, determines the legal status of the merchants, their rights and obligations.

The second book "On Commercial Companies" is devoted to commercial legal entities. The book gives a general description to commercial legal entities; the relevant organizational and legal forms are considered, that include full partnership, simple commandite partnerships, limited liability companies, joint-stock companies (jointstock company, joint-stock commandite partnerships and a simplified joint-stock company) [21].

The third book of the Commercial Code of France contains provisions on exclusive sales terms. In particular, they received legal regulation of non-typical types of alienation, such as liquidation sale, warehousing sale or goods sale in branded stores.

The entrepreneurial nature of the relations governed by the Commercial Code of France provides the codification of antitrust laws and economic concentration laws, the issues the fourth book of the Code is devoted to. The relevant section includes a regulation of anti-competitive actions, conditions for economic concentration, consolidates the provisions of the antimonopoly council, its legal status and procedure for consideration of relevant cases and appeals against decisions of the antimonopoly council [21].

The fifth book of the Commercial Code of France consists of two titles, devoted to the legal regulation of the circulation of commercial securities and the types of commercial obligations. 
The sixth book of the Commercial Code of France contains the norms of legal regulation of the restoration of solvency of the company and the competitive process. Today, the sixth book includes 9 titles, the last changes of which were introduced at the end of 2017, indicating a rather dynamic development of legal regulation of the recovery of solvency ratios in this part of the codified act.

In 2006, the seventh book devoted to the organization of the activity of chambers of commerce and business and the activities of commercial courts was included in the Commercial Code. The procedure for the organization of activity of the chambers of commerce and industry has been substantially improved, the competency of commercial courts, the procedure of their formation, election of governing bodies was established; the jurisdiction of commercial cases was determined, and the administrative principles of the judicial authorities were established.

The eighth book contains provisions for regulated professions that are mentioned in the Code in the process of regulating commercial activity.

Thus, in this section of the Commercial Code of France, the tasks and qualification requirements for court executives, court officials and experts of economic diagnostics of enterprises in the process of restoring the solvency of an enterprise or declaring it bankrupt are set.

Finally, the ninth book contains special warnings concerning the five territories of France: 1) San Pierre and Miquelon; 2) Mayotte; 3) New Caledonia; 4) French Polynesia and 5) Wallis and Futuna Islands.

The contractual law of France is being updated far beyond the borders of the Republic, providing favorable conditions for competition between the legal systems. Thus, the Decree "On Reform of Contractual Law, General Obligations Regime and Evidence of Commitments" no. 2016-131 dated February 10, 2016 provides numerous advantages in terms of "legal certainty" and "economic efficiency" [24].

The report to the President of the Republic states that "the international challenge of such a reform of French law is economical" and explains that "the creation of a more comprehensible and predictable written contractual law, by adopting a simplified style of editing, as well as a more precise and didactic presentation is the factor which can attract foreign investors who want to conclude their contract on the basis of French law". When acquainted with the text itself, in fact, in the final version most of the original text remains unchanged. The said report points to a consensus between the reform project and the final text, which aims to create a more accessible and understandable regulatory and legal act without undermining the authentic and unique style of the Civil Code. In addition, it is reinforced by the country's aspirations to respond to a globalized world where the legal systems are actively competing. French private law shall be modernized in order to maintain the status of the most qualitative law-making in the given sphere, which is potentially eligible for borrowing [25].

During the confrontation, the idea of reproducing French private law as an attractive model of reforming depends on a well-designed image of an updated and modern leg- 
islation directly related to the trends of European integration [26]. It should be noted that the renewed contractual law contains numerous provisions, where confidence, efficiency and justice become the motto of the new law on commitment.

Regarding the Civil Code, it should be noted that for more than two centuries after its adoption, it has remained the main tool of private law in France. The first book of the Civil Code of France "On Individuals" consolidated the general principles for the implementation of civil rights, regulated family relations, defined the civil and legal status of an individual, its location, the procedure for recognizing a person to be missing, establishing guardianship and guardianship, and others like that. It should be noted that this section of the regulatory legal act has undergone the slightest adjustments in view of European integration. It can be argued that in its original form it was significantly ahead of its time.

Nevertheless some parts of the codified act fell under the influence of European integration processes and were modernized in order to meet the norms of today's challenges. In particular, in 2016 a comprehensive reformed, corrected and reorganized section on contractual law entered into force. Normative consolidation of legislative Europeanized transformations marked the end of the existence of the articles of the Code of 1804, familiar to many generations of practitioners and scholars, and at the beginning of a new era 150 articles replaced the previous ones, having consolidating the multilateral aspects of French contractual law. However, it can't be argued that only the sphere of contractual relations fell under perturbation (the Articles 1101-1231-7); among other things reforms were also made in such sectors as "general legal regime of obligations" and "evidence of obligations". Thus, in total 353 new articles were introduced into implementation. In particular, these are the norms of the Civil Code on the duty to provide information, economic violence, adaptation of the treaty on the basis of unpredictable events and unfair terms in the standard form of the treaties. The introduced new items concerned the obligations, treaties, order of their conclusion, content and validity of treaties, changes in their terms, interpretation of the provisions and legal implications of the conclusion of the treaties. It should be noted that despite the fact that the outline changes were the subject of lively discussion and substantial criticism, the norms, beyond doubt, are consistent with the essence of civil law systems, as well as with the latest European and international codifications [24].

Such legislative transformations have become a significant event on the territory of the French Republic, especially in view of the immutability of codified articles on contractual law over a long period of time. The reform was implemented to the full extent, absorbing all the aspirations of previous years, which were affected by the enhanced Europeanization of legislation and attempts to reconcile the sphere of private law with world standards and requirements.

It is worth noting that the classical closure of civil law in France, the code of which is one of the oldest codified legal acts of the world, is currently in a state of convergence 
of law traditions of Western Europe. Evidence of such fact is the dynamic process of reforming the lawfulness of France, in which, in recent years, three draft amendments to the Civil Code have been prepared [27]: the first was developed under the direction of Professor Francois Terre; the second - by a group headed by the Professor Pierre Catala; the authorship of the third one belongs to the Ministry of Justice of France. The main directions of perfection of the French contractual law were defined by the Law "On Modernization and Simplification of Legal Norms and Procedures in the Sphere of Justice and Home Affairs" dated February 16, 2015. The changes made may not be considered as separate amendments to the text of the regulatory and legal act, since all the articles appear as a single array of norms, which includes both the already existed provisions, which were introduced with technical changes, and fundamentally new provisions that regulate the relevant legal relationship.

Prior to the reforms, most articles in the Code of Contractual Law have remained unchanged, even when the society and technology around them changed beyond recognition. Instead, the courts gradually interpreted archaic articles, so the creation of a precedent set of decisions with a list of necessary and already approved changes allowed gradually to accommodate to adaptation.

To summarize, it can be argued that the main results of the reform of French contractual law are the conceptual refusal of the casual nature of many of the rules of the Napoleonic Code. That entails refusing to consolidate single rules for specific situations with their replacement by the general rules and regulations. The new provisions of the Civil Code of the French Republic entered into force on October 1, 2016 and were included into the Book III "On different ways of acquiring property".

Some European norms have been included in this legal act, but this does not mean the final adaptation and implementation of European standards, therefore the European Union's directives on liability for poor quality (defective) products, electronic signatures and electronic commerce have been added to the norms of the Civil Code, while the others have become an integral part of other legislative acts. For example, the Decree on Unfair Terms has been incorporated into the Consumer Code.

Now the adherents of the empirical approach characterize the Community as an innovative legal laboratory. The European Union is rooted in the diversity of member states and their legal cultures, and the rapid development of law leads to profound changes in its understanding. The relationship between French national legislation and EU law has gradually been formed by judges through complex structures that were different from traditional representations based on the pyramid of norms. The above shows that the modern legal system of France is under the influence of tectonic breakdowns that occur in Europe. Consequently, economic integration may not be successfully developed without a proper legal basis, which is the European Union's communitarian law. Despite the fact that 28 states are represented in the association, France and Germany are the centripetal force that forms the institutional scrapers of the communitarian legal system. The synergetic influence of both states on the development of modern European legal thinking 
requires the gradual convergence of the two institutional systems of legal regulation of social relations [28]. This process objectively requires the reform of the country's legislation, bringing it to the needs of those processes of economic integration that take place in Europe. Therefore, in today's conditions, for the modernization of private law, the country must simultaneously maintain unquestionable legal values and be ready to innovate, even at the risk of abandoning some of the law institutions.

\section{DISCUSSION}

The reform of private law and legislation is largely objectively determined, but its effectiveness depends largely on who and how directs and implements relevant processes. Many researchers directly or indirectly associate the adverse socio-economic consequences of the transition to a market economy type in the 90s of the XX century with the effect of private law that did not ensure the proper implementation of the social purpose of civil law, and therefore did not comply with the two main objectives of civilian-legal regulation: the approval of legal order in property relations and the introduction of certainty and stability in these relations by establishing clear rights and obligations of the participants, as well as their responsibility [29].

Scientists note that the transformations in French private law in the context of European integration are somewhat chaotic and associated with the emergence of specific problems of law enforcement in practice [30]. Some justify such a phenomenon by the reluctance to modify outdated norms because of their uniqueness and global significance. The Belgian scientist in the field of civilization and comparative law Marcel Fontaine noted: "In other countries of the world, it is not usual for citizens to be attracted by the international influence of their own law system". That is why the problem and the need for urgent intra-system transformations penetrated French lawyers after the celebration of the bicentennial of the Civil Code and the publication of the World Bank's Doing Business reports, and was compared to the profound influence on global law constructs of the processes of globalization and Europeanization.

The adopted regulatory and legal acts of the latter modern period, designated by us, shall already restore confidence and authority of the French lawyers and economists, thereby contributing to the strengthening of the image of the French Republic in the international arena [31]. The greatest expectations rely on the originality and attractiveness of the new French contractual law. The Professor of the Montpellier University Remi Kabriak notes that the reform of private law in France is characterized by the fact that much of the legislative framework was limited to consolidating the approaches developed earlier in judicial practice. Enhancing the flexibility of the contractual mechanism is a keynote regarding all legislative transformations, facilitating, in particular, the adaptation of contractual law to new contractual models and economic realities [32].

Taking into account the views of scholars, it can be stated that the reform of private law in France in the context of European integration is taking place too slowly and is reflected in its selectivity in improving the legislative framework. Therefore, the most 
urgent and expedient is the author's proposal to develop a Concept for reforming private law of the French Republic, based on the latest trends in the development of this branch of law, European standards and requirements and peculiarities of the country's law system. Practitioners, judges, scholars and international experts should be involved in the development of such a document. It is then that with the development of qualitative route guidance for transformation, the country will be able to create a worthy replacement to the archaic law heritage.

\section{CONCLUSIONS}

Realization of the reformation of the sphere of private law is a priority direction of the state policy of many democratic countries of the world, taking into account the European principles of the construction of society. The new fundamental private law is based primarily on judicial practice, consolidating the approbated and tested ways of regulating social relations. That is why the evolutionary changes that are currently taking place in French law are of great importance for the entire law system of the country and are of considerable interest to the science of comparative law.

The general vector of development of law systems of continental-European orientation has defined as the dominant, first of all, the legislative way of activity in the law-making sphere of modern France. Unfortunately, contrary to the positive transformations, so far, the French law system has not made a quantum leap and partly retained loyalty to the past sovereign development way. Today, within the framework of the Europeanization of rights and politics, the country faces a decisive choice between two determinants: either the independent status of the law system will be preserved, or, if converging pressure is applied, its internal organization will be changed.

The authors noted that the French Civil Code of 1804 (known as the Napoleonic Code) and the Commercial Code of 1807 became the first codified acts among the countries of the Romano-Germanic legal family that systematically formed the basis of the dualism of civil and commercial law of modern Europe.

In turn, in recent years, the most significant changes have taken place in the Civil and Commercial Codes in the field of contractual and binding law. The reforms were featured by their chaotic nature and long-term agreement of legislative proposals.

It should be noted that one of the main results of the performed transformation of French contractual law is the inclusion in the Civil Code of the general provisions on obligations, which for the first time were enshrined in the codified act as a single set of norms, numerous definitions and general provisions for a whole range of civil law institutions. Of course, one of the main features of the reform is to raise the level of abstraction of legal norms. The latter is an unconditional indication of the harmonization of French law with other European private law institutions, in particular those relating to the German legal tradition. Taking into account the foregoing, one can single out the following features of the private law of France: the international and comparative perspective; great ability of self-restriction in order to meet the imperatives of state laws; high degree of formalization. 
As a result of the performed analysis, four periods of the reform of the private law of the French Republic were singled out, in particular: the first "Colbert's period", the second "Napoleonic period", the third "Integration period" and the fourth "Modern period". The most significant changes in the private law of France fall into the integration and modern periods in view of the strengthening of European integration and globalization processes. Moreover, upon the condition of adoption of the comprehensive route guidance for reforms, such as the proposed author's Concept for reforming private law of the French Republic, the country will be able to create a more powerful analogue of the Napoleonic codification and regain winning positions in the world community and become a role model.

\section{REFERENCES}

[1] Zakharova, M. V. (2015). French legal system: problems of theory (Doctoral dissertation, Moscow State Law University named after O. E. Kutafina).

[2] The study adopted by the Conseil d'Etat on "L'influence internationale du droit français". La Documentation française. (2001). Retrieved from http://www.ladocumentationfrancaise.fr/ var/storage/rapports-publics/014000702.pdf.

[3] Cartwright, J. (2016). Whittaker S. The Code Napoléon Rewritten: French Contract Law after the 2016 Reforms (Studies of the Oxford Institute of European and Comparative Law). London: Whittaker Bloomsbury.

[4] Texte intégral de la Constitution du 4 octobre 1958 en vigueur. Retrieved from https:// www.conseil-constitutionnel.fr/le-bloc-de-constitutionnalite/texte-integral-de-laconstitution-du-4-octobre-1958-en-vigueur.

[5] Status and prospects of relations between Ukraine and France. Analytical note. Retrieved from http://www.niss.gov.ua/articles/295/.

[6] Latina, M. (2017). La réforme du droit des contrats en pratique. Paris: Dalloz.

[7] Ancel, F. (2017). Bénédicte Fauvarque-Cosson, Juliette Gest. Aux sources de la réforme $d u$ droit des contrats. Paris: Dalloz.

[8] Terré, F. (2016). La réforme du droit des obligations. Paris: Dalloz.

[9] Stoffel-Munck, P. (2015). Réforme du droit des contrats et pratique des affaires. Paris: Dalloz.

[10] Chantepie, G., Latina, M. (2016). La réforme du droit des obligations. Commentaire théorique et pratique dans l'ordre du Code civil. Paris: Dalloz, 2016.

[11] Kharitonov, Ye.O., Kharitonova, O. I. (2014). Private law as a concept: the search for a paradigm. Odessa: Feniks.

[12] Kabriak, R. (2007). Codings Les codifications. Moscow: Statut, 2007.

[13] Kazakova, O. V. Problems of codification of legislation. Retrieved from https://sibac.info/ conf/law/iii/54465.

[14] Morozov, S. P. (2016). Dualism of private law: traditions and modernity. Law and practice, $1(15), 15-20$.

[15] Rapport au Président de la République du 18 septembre 2000 relatif à l'ordonnance no 2000-912 du 18 septembre 2000 relative à la partie Législative du code de commerce. Retrieved from https://www.legifrance.gouv.fr/affichTexte.do?cidTexte=JORFTE XT000000766906.

[16] Loi constitutionnelle No 92-554 du 25 juin 1992. Retrieved from https://www. conseil-constitutionnel.fr/les-revisions-constitutionnelles/loi-constitutionnelle-n-92-554du-25-juin-1992. 
[17] Zweigert, K., Kötz, H. (1998). On the 'extraordinary influence' of the Civil Code in the world. An Introduction to Comparative Law. Oxford: Oxford University Press.

[18] Fauvarque-Cosson, B., Patris-Godechot, S. (2006). Le code civil face à son destin. Paris: La Documentation Française.

[19] European Parliament Resolution A3-0329/94. Retrieved from https://eur-lex.europa.eu/ legal-content/EN/TXT/?uri=CELEX:52001DC0398.

[20] Communication from the commission to the council and the European parliament on European contract law. Retrieved from http://ec.europa.eu/transparency/regdoc/rep/1/2001/ EN/1-2001-398-EN-F1-1.Pdf.

[21] Code de commerce. Retrieved from https://www.legifrance.gouv.fr/affichCode.do?cidTe $\mathrm{xte}=$ LEGITEXT000005634379.

[22] Ordonnance $n^{\circ} 2000-912$ du 18 septembre 2000 relative à la partie législative du code de commerce. Retrieved from https://www.legifrance.gouv.fr/affichTexte.do?cidTexte=JOR FTEXT000000219662\&categorieLien=id.

[23] Décret $n^{\circ} 2007-431$ du 25 mars 2007 relatif à la partie réglementaire du code de commerce. Retrieved from https://www.legifrance.gouv.fr/affichTexte.do?cidTexte=JORFTEXT000 $000820567 \&$ categorieLien $=\mathrm{id}$.

[24] Fontaine, M. (2016). Le rayonnement international du droit français des contrats. Paris: Dalloz.

[25] Libchaber, R. (2015). Regrets liés à l'avant-projet de réforme du droit des contrats Le sort des engagements non bilatéraux. Revue des contrats, 3, 634.

[26] Mekki, M. (2018). The French Reform of Contract Law: The Art of Redoing Without Undoing. France. Journal of Civil Law Studies, 10, 224-259.

[27] Code civil. Retrieved from https://www.legifrance.gouv.fr/telecharger_pdf.do?cidTexte= LEGITEXT000006070721.

[28] Kharitonov, Ye.O. (2012). Civilian "passionary" type codes: European prototypes. Actual problems of state and law, 66, 7-16.

[29] Zaitsev, V. V., Rybakov, V. A. (2015). Some theoretical issues of civil law development. Law and Economics, 9, 11-13.

[30] Collins, H. (2013). Why Europe needs a Civil Code. European Review of Private Law, 21(4), 907-922.

[31] Chenede, F. (2016). Le nouveau droit des obligations et des contrats. Paris: Dalloz.

[32] Kobiyak, R. Reform of the French treaty law. Retrieved from http://comitasgentium.com/ $\mathrm{ru} / \% \mathrm{D} 1 \% 80 \% \mathrm{D} 0 \% \mathrm{~B} 5 \% \mathrm{D} 1 \% 84 \% \mathrm{D} 0 \% \mathrm{BE} \% \mathrm{D} 1 \% 80 \% \mathrm{D} 0 \% \mathrm{BC} \% \mathrm{D} 0 \% \mathrm{~B} 0-\% \mathrm{D} 1$ $\% 84 \% \mathrm{D} 1 \% 80 \% \mathrm{D0} \% \mathrm{~B} 0 \% \mathrm{D0} \% \mathrm{BD} \% \mathrm{D} 1 \% 86 \% \mathrm{D} 1 \% 83 \% \mathrm{D0} \% \mathrm{~B} 7 \% \mathrm{D} 1 \% 81 \% \mathrm{D0}$ $\%$ BA $\%$ D0 \%BE $\%$ D0 \%B3 \%D0 \%BE- $\%$ D0 \%B4 \%D0 \%BE $\%$ D0 \%B3 \%D0 \%BE $\%$ D0 $\%$ B2 \%D0 \%BE\%D1 \%80 \%D0 \%BD\%D0 \%BE\%D0 \%B3 \%D0 \%BE-\%D0 \%BF\%D1 $\% 80 \%$.

\section{Анатолій Володимирович Коструба}

Доктор юридичних наук, доцент

Професор кафедри цивільного права

Прикарпатський національний університет імені Василя Стефаника 76018, вул. Шевченка, 57, Івано-Франківськ, Україна 


\section{Михайло Михайлович Хоменко}

Кандидат юридичних наук

Доцент кафедри цивільного права

Київський національний університет імені Тараса Шевченка

01033, вул. Володимирська, 60, Київ, Україна

\section{Анатолий Владимирович Коструба}

Доктор юридических наук, доцент

Профессор кафедры гражданского права

Прикарпатский национальный университет имени Василя Стефаника

76018, ул. Шевченко, 57, Ивано-Франковск, Украина

\section{Михаил Михайлович Хоменко}

Кандидат юридических наук

Доцент кафедры гражданского права

Киевский национальный университет имени Тараса Шевченко

01033, ул. Владимирская, 60, Киев, Украина

\section{Anatoly V. Kostruba}

Doctor of Law, Associate Professor, Professor

Department of Civil Law

Vasyl Stefanyk Precarpathian National University

76018, 57 Shevchenko Str., Ivano-Frankivsk, Ukraine

\section{Mykhailo M. Khomenko}

Candidate of Law, Associate Professor

Department of Civil Law

Taras Shevchenko National University of Kyiv

01033, 60 Volodymyrska Str., Kyiv, Ukraine

Рекомендоване цитування: Коструба А. В. Тенденції розвитку приватного права Франції / А. В. Коструба, М. М. Хоменко // Вісн. Нац. акад. прав. наук України. -2018 . - Т. 25, № 2. - С. 156-173.

Suggested Citation: Kostruba, A. V., Khomenko, M. M. (2018). Development Trends Of The Private Law Of France. Journal of the National Academy of Legal Sciences of Ukraine, 25 (2), 156-173.

Стаття надійшла / Submitted: 05.05.2018

Доопрацьовано / Revised: 24.06.2018

Схвалено до друку / Accepted: 27.06.2018 